\title{
THE MISSIONS OF THE ANGLICAN COMMUNION
}

By EUGENE STOCK, D.C.L.

First of all, What is the Anglican Communion? The phrase is a modern one. Ecclesia Anglicana, in Magna Carta, was the Church of England only ; but as the Church spread to other countries, both within and outside the British Empire, and became organized, more or less independently, in those countries, a term was required to indicate the aggregate of Churches, or branches of the Church, thus formed; and 'Anglican Communion' has proved to be a convenient designation.

What Churches, then, are comprised in the Anglican Communion? (1) Five Churches entirely independent of each other, viz., the Church of England, the Church of Wales (which has recently been sundered from it), the Church of Ireland, the Episcopal Church in Scotland, the Protestant Episcopal Church in the United States ; (2) five Churches in self-governing Dominions comprised in the Britjsh Empire, viz., in Canada, Newfoundland, Australia, New Zealand, South Africa; (3) the Church in India, which in its special position stands alone; (4) branches or outlying extensions of the Church in the Crown Colonies and Protectorates of Great Britain, or in the outlying possessions of the United States ; (5) Churches or branches of the Church outside British or American territories, as in China, Japan, Persia, Madagascar and other lands.

Now one of the primary duties of the whole Church of Christ, and therefore of the Churches-indeed of every individual Church-in the Anglican Communion, is to proclaim the divine message of redemption to mankind. 
Our present inquiry, then, is concerning the part which they are taking in the great enterprise of making that message known everywhere. But we have to bear in mind two facts, viz., (1) that there were Anglican missions long before anything like an Anglican Communion was thought of, and (2) that it is some of those very missions which have built up the individual Churches now comprised in that united body.

\section{Missions of Past Centuries}

Let us take the historical point first. Shall we go back to the reign of Queen Anne, when certain Anglican missionary organizations sprang into being? Or still further, to the spacious days of great Elizabeth, when the colonization of distant continents was first planned? But the Ecclesia Anglicana was not born at the Reformation. It was alive, and organized, and at work, a thousand years before that. Even if we pass over the ancient British Church, and the work of St Patrick in making heathen Ireland an 'Island of Saints' and a 'University of the West' for the refuge of European scholars fleeing from continental turmoil, we cannot date it later than Augustine's mission and the foundation of the see of Canterbury in A.D. 597. And it was Anglo-Saxon Christendom that sent forth Boniface, the Apostle of Germany in the eighth century, and pioneers, a little later, to Denmark and Norway. Apparently, however, the English Church had little share in the Franciscan missions of the Middle Ages; and when the great period of exploration arrived, which synchronized with the Reformation period, it was natural that the Spanish and Portuguese nations, being the pioneers of modern geographical discovery, should also be the pioneers of modern missions.

But England quickly followed; and even the rough navigators and settlers of Elizabeth's day contemplated, not the extermination of the native races, but their con- 
version to Christianity. Only a few years ago, the largest stone cross in the world, fifty-seven feet high, was erected by the Bishop of California on a cliff three hundred feet above the sea, to commemorate the solemn church service held by the chaplain of Sir Francis Drake's expedition at its first landing on the Pacific coast in 1579. The first Red Indian convert was baptized in Virginia in 1587; and King James's Charter for the Virginia Colony (1606) provided that 'the word and service of God be preached, planted and used, not only in the said Colony, . . . but also among the savages bordering among them, according to the rites and doctrines of the Church of England.' One of Sir Walter Raleigh's expeditions, in 1603, held church services on the famous spot, afterwards named Plymouth, where the Pilgrim Fathers landed seventeen years later.

The first regular missionary organization in England, however, was not Anglican. In 1648, the House of Commons, under the auspices of Cromwell, established a Society for the Propagation of the Gospel in New England, which raised money to assist John Eliot, the Puritan missionary of Massachusetts. But after the Restoration it was reorganized by Robert Boyle as a church society; and it exists to this day as the New England Company, and disburses its funds in New Brunswick and Nova Scotia. Boyle also bequeathed money to found a Christian Faith Society for the evangelization of Virginia; and this likewise is still at work, but in the West Indies.

The close of that century was an epoch in the history of Anglican missions. In 1698 was founded the Society for Promoting Christian Knowledge (S.P.C.K.), to foster Christian literature and education; and in 1701, the Society for the Propagation of the Gospel (S.P.G.), to provide clergy in foreign parts, that is, the colonies and dependencies of Great Britain, both for the pastoral care of the settlers and for the evangelization of the natives. Soon after this, a call came to aid a Lutheran mission in South India, sent out by the King of Denmark in 1705; 
and, apparently because that was outside the sphere of British influence, the S.P.C.K. responded rather than the S.P.G., although such work was not within its own special functions. It adopted part of the mission, and extended it widely ; and several of the ablest missionaries, including Schwartz, were its agents. They were in Lutheran orders ; but they used the English prayer-book, they assisted the East India Company's chaplains, they reported to the S.P.C.K. ; and S.P.C.K. funds were the main source of their support. This arrangement lasted a century, until 1825 ; but the work, though successful for a time, had its weak points, and was only partially enduring.

\section{S.P.G. AND THE Dominions}

Meanwhile, the principal field of the Society for the Propagation of the Gospel was the American Colonies, until they became the independent United States in 1783 ; and in the eighty years it sent out or maintained nearly 300 clergymen. But it suffered from the drawbacks of an established Church. The permission of the Crown was required for the consecration of a bishop, and the government would not yield to the urgent appeals of the society and extend the episcopate to the colonies. Every colonial candidate for holy orders, therefore, had to cross the Atlantic to obtain them; and of those who faced what was then a dangerous voyage, one-fifth perished at sea. When the United States achieved their independence, the Church there applied to the Scottish Episcopal Church, which did not enjoy the privilege of connexion with the State and was therefore able to respond by consecrating the first American bishop, Samuel Seabury, in 1784. After that, the government gave way. Three more bishops were given to the States, and two to the Canadian Colonies, before the century closed.

The Protestant Episcopal Church of the United States, therefore, so important a member of the Anglican Com- 
munion, is the direct fruit of the early missions of the Mother Church of England. So also are the Churches in the great self-governing Dominions. In the earlier years of them all, the clergy for the pastoral care of the settlers were supplied mainly by the S.P.G.; and in some of them, particularly in South Africa, the same society has undertaken the larger part of the evangelistic work among the aboriginal inhabitants. It began sending clergy to Newfoundland in 1708 ; to the West Indies in 1710; to Nova Scotia in 1728 ; to other Canadian Provinces in 1759; to Australia in 1793; to South Africa in 1820; to Tasmania in 1834; to New Zealand in 1840. By its influence, and its large grants of money, it has taken the lead in establishing and endowing dioceses in them all, and in many other parts of the world. The powerful Churches of Canada, South Africa, Australia, New Zealand, and other lands owe their ecclesiastical life mainly to the S.P.G. The Colonial and Continental Church Society, founded 1838, has, on a smaller scale, also rendered them essential aid.

These great Dominions can now scarcely, with justice to their own Churches, be reckoned as mission fields in the ordinary sense of the words. Their Churches have become partners in the great enterprise of the evangelization of the world, and are conducting their own missions, as we shall presently see. Yet the younger and remoter dioceses still need the help of the Mother Church, and this help is still freely given. Particularly is the claim of Canada upon us admitted and responded to, in view of the immense immigration from our own shores into the prairies and forests of the Far West.

\section{A Branch of Missions often forgotten}

But there is another branch of missions to our kith and kin overseas. There are the British officials, traders, etc., in India, in the Crown Colonies, in the African Protectorates; and in foreign countries like China and South 


\section{International Review of Missions}

America. These are a very important class, though often forgotten by supporters of missions. They are almost everywhere ministered to by clergy supplied from home, largely by the S.P.G. ; also in several places by the Colonial and Continental Church Society, and in Brazil, Argentina and other parts by the South American Missionary Society. In India, the East India Company from early days provided chaplains; and when the non-official Britons increased in number, the (Indian) Additional Clergy Society and the Indian Church Aid Association were established for their benefit, and also for ministrations among the Eurasians (now called Anglo-Indians). The great results that may be achieved by this branch of the Church's work are illustrated by Indian experience. The able and devoted chaplains sent out in the early years of the nineteenth century (Henry Martyn was one) exercised so great an influence upon the officers, both military and civil, that many of these officers became the most zealous and liberal supporters of missions to the non-Christian population. Many of the principal mission stations were established at their request, and largely at their expense. The succession continued to the great Christian rulers and commanders of later days, Henry and John Lawrence, Robert Montgomery, Herbert Edwardes, Bartle Frere, William Muir and a host of others.

\section{Early Missions to Non-Christians}

And this brings us to the Church's missions to nonChristian peoples, which are the largest section of Anglican missionary enterprise. Up to the end of the eighteenth century, however, the only Anglican effort among these heathen peoples were the S.P.C.K. Lutheran mission in South India, before referred to; the small work of the S.P.G. clergy among the Red Indians of the young Canadian colonies; and a one-man mission of the S.P.G. on the West African coast. Some slight impetus to the 
great task was given by the formation of the Church Missionary Society (C.M.S.) in 1799; but the immediate results are commonly much over-stated.

It is important to remember the condition of England at that time. The great war was raging. Taxes were heaped upon taxes; the national debt was rising by leaps and bounds; the Bank of England had stopped payment a year or two earlier; poverty and distress abounded. Religiously, the Methodist Revival had done much good; yet parishes were still largely held by hunting and drinking clergy, many of them pluralists and non-residents; churches were empty; there were hundreds of villages without a Bible and with no school worthy of the name. What chance had the appeal of foreign missions? The S.P.G. and S.P.C.K. were at the lowest level in their long history; and what could the infant and unrecognized C.M.S. do for the great cause at such a time and with such an environment ? It sought for missionaries, but fourteen years passed away before a single English clergyman was available, and it had, like the S.P.C.K., to appeal to Germany ; whence, within those fourteen years, it obtained eleven men in Lutheran orders. Yet this was the period often described as an epoch of missionary enthusiasm. Three events redeemed it from almost total stagnation: the foundation of the Bible Society in 1804; that of the London Jews Society in 1809 ; and the success of Wilberforce in the abolition of the slave trade in $\mathbf{1 8 0 7}$.

But epochs of special interest were coming. The year 1813 was memorable for Wilberforce's second victory securing the free opening of India to missionaries, and the establishment of the bishopric of Calcutta. In 1814 Samuel Marsden started the New Zealand Mission; and in 1816 Sierra Leone began to be a fruitful field. C.M.S. local associations were now being formed in many parts of England: a movement which had important issues, not least in the remarkable revival of the S.P.G., dating from 1818. 


\section{The Hundred Years, 1820-1920}

A whole century has elapsed since then, and the events which even in the briefest adequate summary would require many pages must be compressed into a few lines.

The revived S.P.G. gradually extended its work among non-Christians far and wide. It took over the old S.P.C.K. missions in the Madras Presidency, and soon spread its influence over many parts of the Presidencies of Bengal and Bombay; also to Ceylon and Burma. The vast territories of South Africa became one of its most fruitful fields; and the large islands of Borneo and Madagascar; and the West Indies and British Guiana. In the later years of the century it set on foot important work in North China, Japan and Korea. The C.M.S. gradually took an even larger share of the task of evangelizing the nonChristian peoples; its spheres of labour comprising large provinces in India, Ceylon, Central and South China, Japan; also Persia, Mesopotamia, Palestine, Egypt, the Sudan; also West and East Africa and Uganda; also the Maoris of New Zealand and the Red Indians of North-West Canada. The South American Missionary Society (1844) represents the English Church in what has been called the Neglected Continent. The Universities' Mission to Central Africa, started in 1858 under the inspiration of Livingstone, has done extensive and important work in East Africa, having its headquarters at Zanzibar. The Cambridge Brotherhood joined the S.P.G. Delhi Mission in 1877; the Oxford Mission to Calcutta, and the Cowley Fathers in the Bombay Presidency, began about the same time. The Church of England Zenana Society, an association of women established in 1880, has noble workers in India, Ceylon and China For the larger part of the century the London Jews Society has been busily engaged in Palestine and other parts of the Near East (as well as in Europe); and the Jerusalem and the East Mission, founded by 
Bishop Blyth in 1887, works among both Jews and Moslems. The Archbishop's Mission to the Assyrian Church has aimed at that Church's instruction and revival without proselytism-a task undertaken for other Eastern Churches in earlier days by the C.M.S., not without manifest fruit, particularly in the ancient Syrian Church of South India.

All this while, the Anglican episcopate has been spreading over the world. Its modern extension dates from the establishment of the Colonial Bishoprics Fund in 1841. There were then 10 Anglican dioceses in 'foreign parts.' There are now 132, including 12 founded by the American Church.

\section{Public Events-Great Personalities}

Public events have often affected the progress of Anglican missions, sometimes opening doors for them, sometimes hindering them, sometimes themselves the results, direct or indirect, of missionary enterprise. British operations against the slave trade in both West and East Africa have led to missions on both coasts. The abolition of slavery itself in the West Indies called for the extension of church work there. The tangled history of South Africa, with its Kafir, Zulu and Boer wars, caused both trouble and development. The exploration of Central Africa owes much to the previous journeys and researches of missionaries. Even before Livingstone's great travels, Krapf and Rebmann's discoveries of the mighty East African mountains, Kilimanjaro and Kenia, and their reports of great lakes in the far interior, led to the expeditions of Burton and Speke and other famous travellers. The 'scramble for Africa,' and the British and other European protectorates that ensued, were partly a result of missionary enterprise and partly a cause of its extension. The latest illustrations are the C.M.S. advance into the Central ${ }_{\mathrm{m}}$ Sudan, now in the Protectorate of Nigeria, and 
into the Eastern Sudan since Kitchener's victorious campaign. In India the fresh annexations of provinces, e.g., of the Panjab, Oudh and Burma, have opened doors through which the Church has entered fruitful fields; and so have the successive treaties with China and Japan. The Colony of New Zealand was distinctly a result of the C.M.S. Maori Mission. The history of Anglican missions during the whole century is closely linked with the more general history of the British Empire.

Yet missions owe more to personalities than to events. We look at Africa, and we think of Bishops Gray and Callaway, Mackenzie and Steere, Hannington and Tucker. We think of Robert Bruce in Persia, of Bishops Caldwell and Cotton and French in India, with Noble and Ragland and R. Clark and Pennell ; of Marks in Burma ; of Bishops Russell and Moule and Scott, and Archdeacons Moule and Wolfe, in China; of Bishop E. Bickersteth in Japan; of Bishops Selwyn and Patteson, and the brothers Williams in New Zealand and Melanesia; of Archbishop Machray and Bishops Horden and Bompas and Ridley in NorthWest Canada. And we perceive that the deaths among them which most distressed us at the time proved to be inspiring calls to the Church; witness those of Mackenzie and Patteson and Hannington and French; of G. M. Gordon, killed at Kandahar ; of Robert Stewart, massacred in China ; of Captain Allen Gardiner, perishing in Tierra del Fuego.

\section{Progress at the Home Bage}

The last forty-five years have seen a remarkable growth of missionary zeal and interest at home; and the careful student of modern Anglican history can scarcely miss the conclusion that the starting point of this growth was the first Day of 'Intercession for Missions, Dec. 20, 1872. There had been a period of depression and retrogression. Missionaries were actually fewer in number then they had 
been; and the funds, so far from profiting by that shortage, showed heavy deficits. But God, as ever, proved the hearer and answerer of prayer. Revival came at once. Candidates came forward freely, and the incomes of the societies largely increased. In three respects the missionary ranks showed striking development: university graduates in much augmented numbers dedicated themselves to Christ's service abroad, not only manning the special university missions before mentioned, but, still more, joining the old societies; doctors volunteered for the medical missions which were now rapidly spreading and proving especially useful among Mohammedan peoples, and also in pagan Africa and in China; women came forward as never before, not only for the smaller organizations formed especially for them, but in yet larger numbers for the S.P.G. and C.M.S. The formation of the Student Movement in 1892 gave a great impetus to offers of service.

New home agencies have arisen during the last thirty years. Missionary exhibitions and missionary parochial missions have been numerous and successful. Guilds and unions and bands for clergy, for laymen, for women, for young people have multiplied. Summer schools and study circles have come to the front in the present century. More official, as representing the Church as a body, have been the Boards of Missions, first started by Archbishop Benson in 1887. The Central Board, organized in 1908, has become a powerful body; and the Diocesan Boards are fostering increased interest everywhere. The C.M.S. Centenary in 1899, and the S.P.G. Bicentenary in 1901, were occasions of much thanksgiving for the divine blessing. The Pan-Anglican Congress of 1908, which brought together delegates from Anglican dioceses in all parts of the world, produced important debates and valuable literature; and still more was this the case with the World Missionary Conference at Edinburgh in 1910, which led to the starting of this Review, and to the very fruitful 
visits of Dr J. R. Mott to India and the Far East for the promotion of Christian unity and co-operation.

\section{Missions of Sister and Daughter Churches}

So far we have sketched the progress of the missions of the Church of England. Let us now see what the sister and daughter Churches have been doing.

(a) The Scottish Episcopal Church has taken as its special fields the Diocese of St John's, Kaffraria, in South Africa, and the Chanda district in Central India.

(b) The Church of Ireland contributes largely to the S.P.G. and C.M.S., both in money and in men and women ; and Dublin University has two missions affiliated with those two societies respectively, in the Chota Nagpur district in North India, and in the Fukien province of China. Some of the most distinguished missionaries have been Irish men and women; Bishop Lefroy for example.

(c) The Canadian Church has its official missionary society, which has extensive work among the Red Indians and Eskimo, and two dioceses and bishops of its own abroad, viz. in Central Japan and in the Honan province of China; also it has taken over the C.M.S. mission in the Kangra Valley, North India, within the diocese of Lahore.

(d) The West Indian Church has a mission in West Africa.

(e) The South African Church has much work among the native population, organized in the various dioceses; besides which a small group of churches sends both missionaries and funds to the C.M.S.

(f) The Australian Church has a Board of Missions, which works among the remnants of the aborigines, helps the Melanesian Mission, carries on an important mission in New Guinea, and has lately begun to send men to China and Japan. The Church Missionary Society of Australia, developed from an old C.M.S. auxiliary dating 
from 1820, and now recognized as an affiliated society of the Church, supplies many missionaries to the C.M.S. in East Africa, Egypt and the Sudan, Palestine, India, China and Japan, and supports them. The two bodies now raise between them, in nearly equal shares, over $£ 30,000$ a year for missions.

(g) The New Zealand Church has its own Maori people, and the Melanesian Mission and diocese as an integral part of its organization. It has also a C.M.S. Association supplying missionaries not only to the C.M.S. itself, but to Maori work and to Melanesia.

(h) The American Church, which owes itself to the S.P.G., owes its Domestic and Foreign Missionary Society to the C.M.S. In 1817 its bishops proposed sending to the C.M.S. any candidates it might have for foreign service ; but the C.M.S. urged on them the importance of independent action, and in 1821 the D. and F.M.S. was formed. It has had much arduous work to do in the domestic department, in the distant and scattered settlements of the West, and among the Red Indians and the Negroes; but it has also sent bishops to the negro colony of Liberia in West Africa, and entered upon important enterprises in Eastern Asia. Its bishops and clergy in China and Japan preceded those of the English Church, and have had a large share in building up the native Church in both those great countries. For a few years, in the 'forties, it had a mission in Greece, and a bishop at Constantinople. It has now bishops in Mexico, Cuba, Porto Rico, Haiti, Brazil and the Philippines.

(i) In all the more mature Anglican missions the native Church takes a considerable share in proclaiming the divine message among the surrounding non-Christian population. This has been emphatically the case in West Africa and in Uganda. In India, there are, in addition to similar work, two regular societies, the Indian Missionary Society and the Tinnevelly Missionary Society, both of which support their own missionaries in other 
parts of India where the language is different. The Church in China has organized a new mission of its own in the province of Shensi.

\section{Church Organization}

The fact that the Christian communities gathered out of heathendom are, as just indicated, taking their share in missionary work, shows that some advance has been made in church organization. The great colonial Churches have already been referred to; and they have naturally taken under their wings the Anglican congregations of the aboriginal inhabitants of their territories. The Maoris, for instance, have been absorbed in the Church of New Zealand, the Red Indians of Canada in the Canadian Church, the Zulus and Kafirs in the South African Church. So also the Negroes in the West Indies, and the Negroes, Red Indians, etc., in the United States. Any distinct racial Church for native Christian communities of this kind would be contrary to the whole spirit of the Gospel, which is to combine the races of mankind and not to separate them. But the case is quite different with the great non-Christian peoples of Asia and a large part of Africa. They will be the immense majority in the Anglican Churches organized for their benefit, and they will be, and ought to be, dominant. The absorption in such Churches should eventually be the absorption of white residents in the national Church of the country. In Japan and China the Anglican Christians have organized their Church under (for the present) foreign bishops, but with synods in which natives and foreigners, clergy and laity, sit and vote on equal terms, but the natives form the majority in each case. Practically the same system has been set up in West Africa and Uganda, and in Ceylon. In India there is a preliminary organization of local church councils; but the bishops are making such arrangements as are possible for diocesan and provincial synods. The first 
Indian bishop has been consecrated, for the new diocese of Dornakal; and the first Chinese bishop, as assistant in the diocese of Chekiang. There have been or are African bishops in Liberia and in Nigeria ; but in Nigeria the present men are assistants to the English bishop. Self-support is advancing everywhere, the Church in West Africa taking the front place with its $\mathbf{\$ 0 , 0 0 0}$ a year for its own clergy, churches and schools.

\section{The Aspect and the Prospect}

When this imperfect survey of Anglican missions past and present was written, the dark shadow of the war still shrouded the world in gloom. But the present writer remembers a great missionary meeting thirty years ago, at a time when all East Africa was in confusion owing to the European 'scramble,' and when all the missionaries had been turned out of Uganda. 'The prospect is indeed dark,' said the British Consul-General at Zanzibar in his speech at that meeting. ' No,' said a Mombasa missionary who followed him, 'the aspect is dark, but the prospect is as bright as the promises of God.'

Yes, even the late war shall turn out for the furtherance of the Gospel. The day will come when we shall look back and exclaim, in Nehemiah's words, 'Our God turned that curse into a blẹssing.'

Eugene Stock 